\title{
Elevational distribution ranges of vascular plant species in the Baekdudaegan mountain range, South Korea
}

\author{
Sookyung Shin ${ }^{1}$, Jung-Hyun Kim², Ji-Hee Dang ${ }^{1}$, In-Soon Seo ${ }^{1}$ and Byoung Yoon Lee ${ }^{2^{*}}$
}

\begin{abstract}
The climate is changing rapidly, and this may pose a major threat to global biodiversity. One of the most distinctive consequences of climate change is the poleward and/or upward shift of species distribution ranges associated with increasing temperatures, resulting in a change of species composition and community structure in the forest ecosystems. The Baekdudaegan mountain range connects most forests from the lowland to the subalpine zone in South Korea and is therefore recognized as one of the most important biodiversity hotspots. This study was conducted to understand the distribution range of vascular plants along elevational gradients through field surveys in the six national parks of the Baekdudaegan mountain range. We identified the upper and lower distribution limits of a total of 873 taxa of vascular plants with 117 families, 418 genera, 793 species, 14 subspecies, 62 varieties, two forms, and two hybrids. A total of 12 conifers were recorded along the elevational gradient. The distribution ranges of Abies koreana, Picea jezoensis, Pinus pumila, and Thuja koraiensis were limited to over $1000 \mathrm{~m}$ above sea level. We also identified 21 broad-leaved trees in the subalpine zone. A total of 45 Korean endemic plant species were observed, and of these, 15 taxa (including Aconitum chiisanense and Hanabusaya asiatica) showed a narrow distribution range in the subalpine zone. Our study provides valuable information on the current elevational distribution ranges of vascular plants in the six national parks of South Korea, which could serve as a baseline for vertical shifts under future climate change.
\end{abstract}

Keywords: Baekdudaegan, Climate change, Elevational distribution, Range limits, Subalpine zone, Vascular plants

\section{Background}

In the past 130 years, the average global temperature has risen by approximately $0.85^{\circ} \mathrm{C}$, and by 2100 , it is likely to increase by $1.9-5.2^{\circ} \mathrm{C}$, depending on the level of greenhouse gas emissions (National Institute of Meteorological Sciences 2019). Species faced with climate change are responding in several different ways, a movement/shift to more suitable habitats, persistence in situ, or a combination of these processes (Dawson et al. 2011; Cahill et al. 2014). One of the most distinctive consequences to climate

\footnotetext{
* Correspondence: bylee80@korea.kr

${ }^{2}$ Department of Biological Resources Research, National Institute of Biological Resources, Incheon 22689, Republic of Korea

Full list of author information is available at the end of the article
}

change is the poleward and/or the upward shift of species distribution ranges associated with warming temperatures (Lenoir et al. 2008; VanDerWal et al. 2012). Using a meta-analysis, Chen et al. (2011) estimated that the species distribution has recently shifted to higher elevations at a median rate of 11.0 $\mathrm{m} /$ decade and to higher latitudes at a median rate of $16.9 \mathrm{~km} /$ decade. This speed is about $2-3$ times faster than a previous study $(6.1 \mathrm{~km} /$ decade northward and $6.1 \mathrm{~m} /$ decade upward) by Parmesan and Yohe (2003). The velocity of future climate change is expected to be high (Loarie et al. 2009) and may largely outpace the potential of species to adapt (Jump and Peñuelas 2005). This induces subsequent reactions such as elevated mortality and reproductive decline in climate-

(c) The Author(s). 2021 Open Access This article is licensed under a Creative Commons Attribution 4.0 International License, which permits use, sharing, adaptation, distribution and reproduction in any medium or format, as long as you give

appropriate credit to the original author(s) and the source, provide a link to the Creative Commons licence, and indicate if changes were made. The images or other third party material in this article are included in the article's Creative Commons licence, unless indicated otherwise in a credit line to the material. If material is not included in the article's Creative Commons licence and your intended use is not permitted by statutory regulation or exceeds the permitted use, you will need to obtain permission directly from the copyright holder. To view a copy of this licence, visit http://creativecommons.org/licenses/by/4.0/ 
sensitive species and ecosystems, leading to the extinction of local population that can no longer move to habitats with suitable climate conditions (e.g., alpine species) (Kong et al. 2014; Wiens 2016; Conlisk et al. 2017).

South Korea is surrounded by the sea on three sides, a mostly mountainous terrain covers $64 \%$ of its land area, and it experiences diverse patterns of climate from a cold continental climate to a warm oceanic climate (Yi 2011). These traits provide excellent conditions for high biodiversity. The average temperature in South Korea has risen $1.8^{\circ} \mathrm{C}$ over the past 100 years, exceeding the global average rate, and is expected to increase by $0.63{ }^{\circ} \mathrm{C}$ every 10 years to 2100 under the Representative Concentration Pathway (RCP) 8.5 scenario (National Institute of Meteorological Sciences 2019). Species distribution ranges and community structure in the forest ecosystems of South Korea are already shifting under climate warming (Kong 2001; Kim 2016; Lee and Kwon 2017). For example, 57 evergreen broad-leaved trees such as Elaeagnus macrophllya and Machilus thunbergii moved over $14-74 \mathrm{~km}$ to higher latitudes over $\sim 60$ years (Yun et al. 2011). The area of the subalpine coniferous forest has decreased by 25\% (from 9327 to 6990 ha) over 20 years (Kim et al. 2019). If the average temperature rises by $1{ }^{\circ} \mathrm{C}$ over the next 100 years in South Korea, the climate zone will move approximately $150 \mathrm{~km}$ northward and $150 \mathrm{~m}$ upward (Kong 2007). Studies on changes in species' distribution ranges under future climate change have forecasted the expansion of potential habitats for the evergreen broad-leaved trees (e.g., Camellia japonica) and the contraction of potential habitats for the subalpine plant species (e.g., Abies holophylla, Taxus cuspidate, and Betula ermanii) as temperature rises (Park et al. 2016; Adhikari et al. 2018).

The Baekdudaegan is a mountain range which runs through most of the length of the Korean Peninsula, and $86 \%$ of the total area $(275,077 \mathrm{ha})$ is designated as a protected area (i.e., the Baekdudaegan Mountain Reserve) (Baekdudaegan National Arboretum 2019). The Baekdudaegan mountain range connects most forests in South Korea and includes the southern, central, and northern temperate zones (Yi 2011; Korea Forest Service 2015). In particular, it is also a major glacial refugium at the Last Glacial Maximum for the boreal and temperate flora of northeastern Asia (Chung et al. 2018). Thus, the Baekdudaegan is well known as one of the most important biodiversity hotspots in South Korea, containing a total of 1867 taxa of vascular plants with 136 families and 566 genera (Korea Forest Service 2015). Contemporary plant range shifts are most frequently reported from mountainous regions, with elevational shifts being the most commonly documented response to increasing temperatures (Jump et al. 2009). The Baekdudaegan is divided into four vegetation zones along an elevational gradient: temperate deciduous broad-leaved and pine forests below $550 \mathrm{~m}$ above sea level (a.s.l.), deciduous broad-leaved and coniferous mixed forests between 550 and $1100 \mathrm{~m}$, subalpine coniferous forest between 1100 and $1600 \mathrm{~m}$, and dwarf subalpine forest above $1600 \mathrm{~m}$ (Kong 2007; Lee and Chun 2016). In response to climate change, mountain plants on the Baekdudaegan are expected to migrate to higher elevations than their currently occupied location. Previous studies have focused on vegetation structure and species composition of the forest ecosystem in the Baekdudaegan range (Kim et al. 2018; Hwang et al. 2020). However, data describing only the fact that a species is present, without information on its latitudinal and elevational distribution ranges, are insufficient to understand the shift in species' response to future climate change. The Baekdudaegan includes three horizontal areas of the Korean Peninsula and wide elevational gradients (that enable vertical shifts in plant location) from the lowland to the subalpine zone. Therefore, the Baekdudaegan Mountains are a key place to identify the shifts and/or movement in the response of species to future climate change in South Korea.

This study was conducted to understand the distribution range of vascular plants along elevational gradients in the six national parks on the Baekdudaegan mountain range. Elevation often connotes local temperature and precipitation features and has long been considered an important determinant of species distribution in mountain habitats (Körner 2007). Thus, we have been constantly investigating the elevational distribution of vascular plants in the national parks through field surveys: Mts. Jirisan (Yun et al. 2010), Seoraksan (Yun et al. 2012), Deogyusan (Kim et al. 2015a), Odaesan (An et al. 2017), Taebaeksan (An et al. 2019), and Sobaeksan (Park et al. 2020). Here, we constructed a dataset on the upper and lower distribution limits of the vascular plants in the Baekdudaegan that integrates these survey data. The discussion then focuses on the elevational ranges of the conifers, broad-leaved trees in the subalpine zone, and Korean endemic plants and their vulnerability to climate change.

\section{Materials and methods}

This study was conducted in the six national parks belonging to the Baekdudaegan mountain range in South Korea (Fig. 1a). The survey route of each site was as follows (Fig. 1b-g): Seoraksan National Park (SR, hereafter) is about $5.0 \mathrm{~km}$ from Osaekgyo (345 m a.s.l.) to Daecheongbong $(1708 \mathrm{~m})$. Odaesan National Park (OD, hereafter) is about $4.8 \mathrm{~km}$ from the autocampsite $(800 \mathrm{~m})$ to the top of the Gyebangsan (1577 $\mathrm{m})$. Taebaeksan National Park (TB, hereafter) is about $3.7 \mathrm{~km}$ from the Baekdansa Ticket Booth $(874 \mathrm{~m})$ to Cheonjedan $(1560 \mathrm{~m})$. Sobaeksan National Park (SB, 


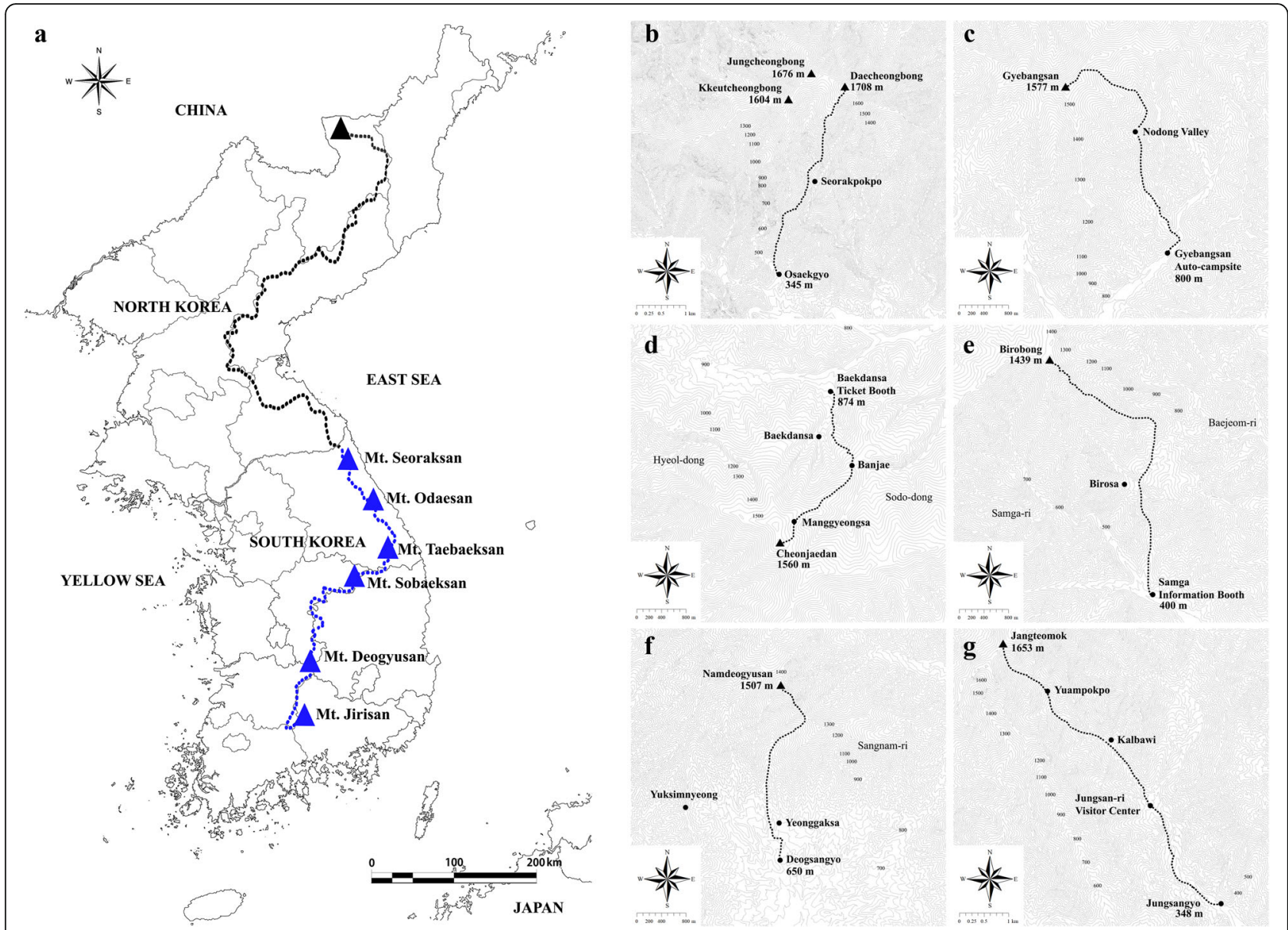

Fig. 1 The six national parks surveyed in the Baekdudaegan mountain range. a Location of the six national parks. b The survey route of Seoraksan National Park. c The survey route of Odaesan National Park. d The survey route of Taebaeksan National Park. e The survey route of Sobaeksan National Park. $\mathbf{f}$ The survey route of Deogyusan National Park. $\mathbf{g}$ The survey route of Jirisan National Park

hereafter) is about $5.5 \mathrm{~km}$ from the Samga Information Booth $(400 \mathrm{~m})$ to Birobong (1439 m). Deogyusan National Park (DG, hereafter) is $3.6 \mathrm{~km}$ from Deogsangyo $(650 \mathrm{~m})$ to the top of the Namdeogyusan $(1507 \mathrm{~m})$. Jirisan National Park (JR, hereafter) is about $5.3 \mathrm{~km}$ from Jungsangyo (348 m) to Jangteumok (1653 m). The survey route in the five sites (SR, OD, SB, DG, and JR) was selected on a south-facing slope. In TB, a north-facing slope was selected because a south-facing slope could not be accessed from a trail.

Field surveys were conducted over 10 years from May 2009 to September 2018 (Table 1). In particular, for JR (Yun et al. 2010), SR (Yun et al. 2012), and DG (Kim et al. 2015a), several taxa were updated in this study through supplementary surveys. The survey route was divided into elevation bands at 100-m intervals from 300 to $1700 \mathrm{~m}$ a.s.l. We recorded all vascular plants within of $5 \mathrm{~m}$ of both sides of the trail in each elevation band. Coordinates and elevation of species were measured using a GPS device (Garmin GPSMAP 60CSx) with the accuracy to within $10 \mathrm{~m}$ at a $95 \%$ confidence level. Collected plants were identified based on the flora guidebook (Lee 2003; Korean Fern Society 2005; Lee 2006; Kim and Kim 2011) and prepared as dry specimens. All voucher specimens were deposited at the Herbarium of the $\mathrm{Na}$ tional Institute Biological Resources in Korea (KB).

The vascular plants were listed according to the classification system by Cronquist (1981) and scientific names were referred to in the National List of Species of Korea (National Institute of Biological Resources 2019a). We also excluded several planting species (e.g., Ginkgo biloba and Parthenocissus quinquefolia) and cultivars (e.g., Saxifraga stolonifera and Lycoris radiata) but included artificial afforestation tree species from our database. Korean endemic plants were classified according to Nam et al. (2018).

\section{Results and discussion}

Quantifying plant species' distributional ranges in their current condition is an essential step in identifying range 
Table 1 Survey description in the six national parks of the Baekdudaegan mountain range, South Korea

\begin{tabular}{|c|c|c|c|c|c|c|c|}
\hline Site & Code & Survey route & Slope & Elevation $(\mathrm{m})$ & $\begin{array}{l}\text { Distance } \\
(\mathrm{km})\end{array}$ & $\begin{array}{l}\text { No. of } \\
\text { bands }\end{array}$ & Survey period \\
\hline Seoraksan National Park & SR & Osaek zone & South & $345-1708$ & 5.0 & 14 & $\begin{array}{l}\text { 03-05 Jun., 29-30 Sep., and } 01 \text { Oct. 2010; } \\
\text { 16-18 May 2011; 02-03 Jun. 2015; 12-13 Sep. } 2018\end{array}$ \\
\hline Odaesan National Park & OD & Gyebangsan zone & South & $800-1577$ & 4.8 & 8 & $\begin{array}{l}02 \text { May 2009; } 31 \text { Aug. 2012; 02-04 May, 04-06 Jul., } \\
09-11 \text { Aug., and 05-07 Oct. } 2016\end{array}$ \\
\hline Taebaeksan National Park & TB & Baekdansa zone & North & $874-1560$ & 3.7 & 8 & 10-12 May, 04-06 Jul., 06-08 Sep., and 16-18 Oct. 2017 \\
\hline Sobaeksan National Park & SB & Samga zone & South & $400-1439$ & 5.5 & 11 & 18-20 Apr., 14-15 Jun., 23-24 Aug., and 24-25 Oct. 2017 \\
\hline Deogyusan National Park & DG & Namdeogyu zone & South & $650-1507$ & 3.6 & 9 & $\begin{array}{l}\text { 15-17 Apr., 24-26 Jun., } 30 \text { Sep., and 01-02 Oct. 2013; } \\
\text { 05-06 Sep. } 2018\end{array}$ \\
\hline Jirisan National Park & $J R$ & Jungsalri zone & South & $348-1653$ & 5.3 & 14 & $\begin{array}{l}\text { 12-14 May, 08-09 Jul., and 14-15 Sep. 2009; 03-04 } \\
\text { Sep. } 2018\end{array}$ \\
\hline
\end{tabular}

shifts in response to future climate warming. This is the first study to reveal the elevational distribution of vascular plants through on-site surveys in the six major national parks belonging to the Baekdudaegan mountain range. We identified the upper and lower distribution limits of 873 taxa of vascular plants with a total of 117 families, 418 genera, 793 species, 14 subspecies, 62 varieties, two forms, and two hybrids (see Additional file 1). They included 43 taxa of Pteridophyta (14 families, 22 genera, 39 species, one subspecies, two varieties, and one hybrid), 12 taxa of Gymnospermae (four families, eight genera, and 12 species), 631 taxa of Dicotyledoneae (88 families, 303 genera, 572 species, 12 subspecies, 45 varieties, one form, and one hybrid), and 187 taxa of Monocotyledoneae (11 families, 85 genera, 170 species, one subspecies, 15 varieties, and one form) in Angiospermae.

Shifts in species distribution associated with warming temperatures occur in two processes: expansion at the cold-edges (higher latitudes and elevations) and contraction of warm-edges (lower latitudes and elevations) (Cahill et al. 2014; Wiens 2016). In case of plants in subalpine zones that must survive by upward shifts, local extinction may occur through the contraction of warm edges if the proper habitat for survival rapidly narrows as the temperature rises. Thus, we identified several taxa (e.g., Pinus pumila, Alnus mandshurica, and Hanabusaya asiatica) with limited distribution in the subalpine zone of cool and cold environments.

\section{Distribution range of conifers}

A total of 30 conifers belonging to 4 families and 10 genera are naturally distributed in South Korea (Kong 2004). Here, we recorded the distribution range of 12 conifer species belonging to four families and eight genera along the elevational gradient at each national park on the Baekdudaegan (Table 2). Pinus densiflora is the most widely distributed conifer species, with a range from the southern islands and coasts to the northern high mountains. It is a dominant species of coniferous forest and accounts for $25.9 \%$ of all forests in South
Korea (Kong 2006; Korea Forest Service 2016). In our survey, $P$. densiflora was consistently observed at elevations ranging from 300 to $1600 \mathrm{~m}$ in SR, OD, TB, and $\mathrm{SB}$ of the northern province. In DG and JR in the southern province, it was observed below $800 \mathrm{~m}$. Recently, the decline of pine forests has happened due to various disturbances such as insect pests, fires, and extreme climate, but mass death has also been reported, especially in the southern province (Chun and Lee 2013; Ko et al. 2014). The death rate of $P$. densiflora is known to increase by $1.01 \%$ for every $1{ }^{\circ} \mathrm{C}$ increase in winter temperatures (Kim et al. 2015b). The future distribution of $P$. densiflora is predicted to steadily decrease due to rising temperatures. In the 2070s, the distributional ranges of this species will be restricted to the Gangwon-do and Gyeongsang-do provinces (Cho et al. 2020). Warming is likely to induce change at the cold- and warm-edges where pine trees are currently distributed.

Conifers on subalpine and/or alpine regions are considered to be one of the most vulnerable species to climate change (Fragnière et al. 2015; Kim et al. 2019). In South Korea, the subalpine coniferous forests are mainly distributed along the Baekdudaegan, and the natural habitat area of subalpine conifers (including Abies koreana, A. nephrolepis, Picea jezoensis, Pinus pumila, and Taxus cuspidata) reaches $71 \mathrm{~km}^{2}$ (Park et al. 2019). In our study, the six subalpine conifers were identified as Abies koreana, A. nephrolepis, Picea jezoensis, Pinus pumila, Thuja koraiensis, and Taxus cuspidata (Table 2). Abies nephrolepis, which is a common coniferous tree species in the subalpine zone of the Baekdudaegan, was consistently observed at elevations ranging from 800 to $1700 \mathrm{~m}$. The latitudinal and altitudinal distribution range of $A$. koreana was limited to above $1000 \mathrm{~m}$ in DG and JR of the southern province. In particular, Pinus pumila and Thuja koraiensis were observed only at the top of SR (1600-1700 m).

Recently, population declines caused by poor growth and mass deaths have occurred in the coniferous communities in the subalpine zone related to high 
Table 2 Distribution range of the conifers observed in the six national parks of the Baekdudaegan mountain range

\begin{tabular}{|c|c|c|c|c|c|c|c|}
\hline \multirow[t]{2}{*}{ Family } & \multirow[t]{2}{*}{ Scientific name } & \multicolumn{6}{|c|}{ Site/elevation $(\times 100 \mathrm{~m})$} \\
\hline & & SR & OD & TB & SB & DG & $\mathbf{J R}$ \\
\hline \multirow[t]{8}{*}{ Pinaceae } & Abies holophylla Maxim. & $4-13$ & $8-15$ & & & $6-12$ & $10-15$ \\
\hline & Abies koreana E.H. Wilson & & & & & $14-15$ & $10-17$ \\
\hline & Abies nephrolepis (Trautv. ex Maxim.) Maxim. & $10-17$ & $11-16$ & $12-16$ & $8-10$ & & $12-17$ \\
\hline & Larix kaempferi (Lamb.) Carrière & $4-5$ & $8-11$ & $9-16$ & $4-15$ & & $5-10$ \\
\hline & Picea jezoensis (Siebold \& Zucc.) Carrière & & & & & $14-15$ & $16-17$ \\
\hline & Pinus densiflora Siebold \& Zucc. & $3-16$ & $8-16$ & $8-13$ & $4-15$ & $6-8$ & $5-7$ \\
\hline & Pinus koraiensis Siebold \& Zucc. & $4-17$ & $8-16$ & $8-16$ & $6-13$ & $6-15$ & $5-17$ \\
\hline & Pinus pumila (Pall.) Regel & $16-17$ & & & & & \\
\hline \multirow[t]{2}{*}{ Cupressaceae } & Juniperus rigida Siebold \& Zucc. & & & & $4-5$ & & \\
\hline & Thuja koraiensis Nakai & $16-17$ & & & & & \\
\hline Cephalotaxaceae & Cephalotaxus harringtonia (Knight ex Forbes) K. Koch & & & & & $6-12$ & $10-11$ \\
\hline Taxaceae & Taxus cuspidata Siebold \& Zucc. & $16-17$ & $13-16$ & $13-16$ & $9-15$ & & $16-17$ \\
\hline
\end{tabular}

SR Seoraksan National Park, OD Odaesan National Park, TB Taebaeksan National Park, SB Sobaeksan National Park, DG Deogyusan National Park, JR Jirisan National Park

temperatures and moisture stress in winter (Kim and Lee 2013; Koo and Kim 2020). For example, the distribution area of $A$. koreana in JR has decreased by $18 \%$ during the 27-year period since 1981 (262 to $216 \mathrm{ha}$ ), and the mortality rate has increased two to five times over the past decade (Kim and Lee 2013). In particular, declining trends were more concentrated in the lower elevation zone (Jump et al. 2009), and declines in the lowelevation, subalpine tree populations have outpaced growth in high-elevation populations due to warming (Conlisk et al. 2017). For example, the death rate of $A$. nephrolepis was highest at $1200-1400 \mathrm{~m}$ in elevation, and its vitality was highest above $1400 \mathrm{~m}$ (Lee 2013). However, the alpine species populations distributed at the mountain peak no longer have a niche that can shift to the leading edge of a cool and cold environment, and in our study, Pinus pumila and Thuja koraiensis were in this situation.

\section{Broad-leaved trees on the subalpine zone in cold and cool environments}

Rising temperatures and moisture stress have caused mass death in the populations of the trailing edges of Fagus spp. and Populus spp., and thus climate change is considered to be a crisis for broad-leaved tree species in cold environments (Geßler et al. 2007; Worrall et al. 2013). In this study, we identified 21 broad-leaved trees belonging to 11 families, 14 genera, one variety, and 20 species that are at the lower distribution limit above $1000 \mathrm{~m}$ a.s.l. (Table 3). Betula ermanii, which is a representative broad-leaved tree species in the subalpine zone of the Baekdudaegan range, was steadily observed at elevations ranging from 1000 to $1700 \mathrm{~m}$ in the six national parks. However, this species is predicted to decrease in the 2070s under the RCP 4.5 scenario, and the range of potential habitats will be in some areas of Gangwon-do, Mt. Jirisan, and Mt. Hallasan (National Institute of Biological Resources 2018). Betula ermanii, which is designated as a climate-sensitive biological indicator species (National Institute of Biological Resources 2019b), is considered to be a representative species of the two processes of distributional shift in response to global warming.

Several woody species have limited distribution in both latitudinal and altitudinal distribution ranges (Table 3). Elevational distribution ranges of Clematis fusca var. flabellata, Alnus mandshurica, Rhododendron brachycarpum, Rosa koreana, and Oplopanax elatus were very narrow over $1500 \mathrm{~m}$ in SR. Rhododendron tschonoskii and Rosa davurica were also observed only at high altitude in DG (1300-1500 m) and JR (1600-1700 m), respectively. The extreme environment (e.g., strong winds, severe annual ranges in temperature) of the subalpine zone and the biological traits (e.g., poor recruitment) are likely to interact with climate change, which will cause the local extinction of the remnant populations (Kong et al. 2014; Wiens 2016). Rhododendron brachycarpum grows naturally in the alpine zone over $1200 \mathrm{~m}$ in the Baekdudaegan (Lee and Shim 2011). In our survey, this species was only observed on mountain peaks in the SR (1600-1700 m). Current climatic conditions may have already restricted the productivity, which in turn limits the population size and total number of individuals. The habitats areas of $R$. brachycarpum have decreased dramatically due to the poor recruitment, over-collection, damage by insects, and unusual temperatures (Lee and Shim 2011) and are likely to be more threatened in the future. The most obvious factor inducing local 
Table 3 Distribution range of the broad-leaved trees observed on the subalpine zone in the six national parks of the Baekdudaegan mountain range

\begin{tabular}{|c|c|c|c|c|c|c|c|}
\hline \multirow[t]{2}{*}{ Family } & \multirow[t]{2}{*}{ Scientific name } & \multicolumn{6}{|c|}{ Site/elevation $(\times 100 \mathrm{~m})$} \\
\hline & & SR & OD & TB & SB & DG & JR \\
\hline \multirow[t]{2}{*}{ Ranunculaceae } & Clematis fusca var. flabellata (Nakai) J.S. Kim & $15-17$ & & & & & \\
\hline & Clematis koreana Kom. & $14-17$ & $14-16$ & $13-16$ & $10-11$ & $12-15$ & $14-17$ \\
\hline \multirow[t]{3}{*}{ Betulaceae } & Alnus mandshurica (Callier) Hand.-Mazz. & $16-17$ & & & & & \\
\hline & Betula chinensis Maxim. & $11-17$ & & & $10-12$ & $14-15$ & \\
\hline & Betula ermanii Cham. & $11-17$ & $12-16$ & $10-16$ & $11-15$ & $11-15$ & $11-17$ \\
\hline \multirow[t]{2}{*}{ Ericaceae } & Rhododendron brachycarpum D. Don ex G. Don & $16-17$ & & & & & \\
\hline & Rhododendron tschonoskii Maxim. & & & & & $13-15$ & \\
\hline \multirow[t]{4}{*}{ Rosaceae } & Rosa acicularis Lindl. & $14-17$ & $15-16$ & $15-16$ & & & $16-17$ \\
\hline & Rosa davurica Pall. & & & & & & $16-17$ \\
\hline & Rosa koreana Kom. & $16-17$ & & & & & \\
\hline & Spiraea chamaedryfolia L. & & $15-16$ & & & & \\
\hline Celastraceae & Euonymus sachalinensis (F. Schmidt) Maxim. & & $10-15$ & & & $12-15$ & $13-14$ \\
\hline Rhamnaceae & Rhamnus davurica Pall. & & & & & & $12-15$ \\
\hline Aceraceae & Acer ukurunduense Trautv. \& C.A. Mey. & & $10-16$ & & & $14-15$ & $11-16$ \\
\hline Araliaceae & Oplopanax elatus (Nakai) Nakai & $16-17$ & & & & & \\
\hline \multirow[t]{2}{*}{ Oleaceae } & Fraxinus chiisanensis Nakai & & & & & $10-13$ & $15-16$ \\
\hline & Syringa wolfii C.K. Schneid. & $14-17$ & $13-16$ & $14-16$ & & & \\
\hline \multirow[t]{3}{*}{ Caprifoliaceae } & Lonicera caerulea L. & $16-17$ & $15-16$ & & & & \\
\hline & Lonicera chrysantha Turcz. ex Ledeb. & & $10-14$ & & & & \\
\hline & Lonicera maximowiczii (Rupr.) Regel & $15-17$ & $15-16$ & $14-16$ & & & \\
\hline Viburnaceae & Viburnum dilatatum Thunb. & & & $12-13$ & & & \\
\hline
\end{tabular}

SR Seoraksan National Park, OD Odaesan National Park, TB Taebaeksan National Park, SB Sobaeksan National Park, DG Deogyusan National Park, JR Jirisan National Park

extinction of a species is that of temperature exceeding the physiological tolerance (Cahill et al. 2013). In the case of Rhododendron tschonoskii, it is predicted that the distribution range of the species will be further reduced if the August maximum temperature average of DG rises by $0.6{ }^{\circ} \mathrm{C}$ from the current condition (Lee 2011). Remarkably, Rosa koreana is predicted to disappear if the August maximum temperature average of SR rises by $0.3^{\circ} \mathrm{C}$ (Lee 2011).

\section{Elevational range of Korean endemic plants, especially subalpine species}

The endemic plant species comprised a total of 45 taxa from 23 families, 39 genera, 41 species, and four varieties in our study (Table 4), constituting $9.8 \%$ of the 459 Korean endemic plants (Nam et al. 2018). Aster koraiensis was observed at relatively low elevations ranging from 400 to $700 \mathrm{~m}$ in SB and JR. Stewartia koreana was observed consistently from the lowlands (600 m a.s.l.) to high altitudes $(1500 \mathrm{~m})$ in DG and JR. Weigela subsessilis was observed from the lowland $(400 \mathrm{~m})$ to the subalpine zone $(1600 \mathrm{~m})$ in the national parks, except for SR and TB. Of these, the lower limits of 15 taxa (including
Pseudostellaria setulosa, Fraxinus chiisanensis, and Scrophularia koraiensis) were restricted to an elevation of $1000 \mathrm{~m}$ across the six national parks.

Endemic species with relatively narrow niches may be especially vulnerable to extinction under a changing climate due to the enhanced difficulty they face in migrating to suitable new sites (Damschen et al. 2010). In general, plant species richness is known to show a pattern of decreasing or hump-shaped distribution with elevational increases, but in the case of endemic species, the ratio increases with altitude (Trigas et al. 2013). The warming amplification has an absolute influence on the survival of growing plant species, and the rate of warming is amplified with elevation (Mountain Research Initiative EDW Working Group 2015). For example, the annual average temperature of Banyabong Peak has increased by approximately $2.8^{\circ} \mathrm{C}$ in 2019 compared to 2012, while that of the lowland (Namwon-si) rose about $1.1^{\circ} \mathrm{C}$. In our study, Aconitum chiisanense (1200-1700 m), Hanabusaya asiatica (1600-1700 m), and Saussurea diamantica (1000-1600 m) were only observed in the subalpine zone of SR. Iris odaesanensis (1500-1600 $\mathrm{m}$ in TB), Allium thubergii var. teretifolium (1300-1500 $\mathrm{m}$ in 
Table 4 Distribution range of the Korean endemic plant species observed in the six national parks of the Baekdudaegan mountain range

\begin{tabular}{|c|c|c|c|c|c|c|c|}
\hline \multirow[t]{2}{*}{ Family } & \multirow[t]{2}{*}{ Scientific name } & \multicolumn{6}{|c|}{ Site/elevation $(\times 100 \mathrm{~m})$} \\
\hline & & SR & OD & TB & SB & DG & $\mathrm{JR}$ \\
\hline Pinaceae & Abies koreana E.H. Wilson & & & & & $14-15$ & $10-17$ \\
\hline \multirow[t]{7}{*}{ Ranunculaceae } & Aconitum chiisanense Nakai & $12-17$ & & & & & \\
\hline & Aconitum pseudolaeve Nakai & & & $8-16$ & & & \\
\hline & Anemone koraiensis Nakai & & & $8-13$ & & & \\
\hline & Cimicifuga austrokoreana H.W. Lee \& C.W. Park & & & & & & $12-15$ \\
\hline & Clematis trichotoma Nakai & & $8-11$ & $8-9$ & $4-7$ & $8-9$ & $6-7$ \\
\hline & Thalictrum actaefolium var. brevistylum Nakai & & & & & $6-11$ & \\
\hline & Thalictrum uchiyamae Nakai & & & & & & $9-10$ \\
\hline Papaveraceae & Coreanomecon hylomeconoides Nakai & & & & & & $6-7$ \\
\hline Fumariaceae & Corydalis maculata B.U. Oh \& Y.S. Kim & $4-10$ & & & & & \\
\hline Caryophyllaceae & Pseudostellaria setulosa Ohwi & $16-17$ & & $11-16$ & & & \\
\hline Theaceae & Stewartia koreana Nakai ex Rehder & & & & & $6-11$ & $7-15$ \\
\hline Salicaceae & Salix koriyanagi Kimura ex Goerz & & $8-9$ & $8-16$ & $6-7$ & $6-7$ & \\
\hline Brassicaceae & Arabis columnaris Nakai & & & & & & $16-17$ \\
\hline Ericaceae & Vaccinium hirtum var. koreanum (Nakai) Kitam. & $8-17$ & $15-16$ & $13-16$ & $8-14$ & $14-15$ & \\
\hline Geraniaceae & Geranium koreanum Kom. & & $14-16$ & $8-16$ & & & \\
\hline Apiaceae & Angelica reflexa B.Y. Lee & & $8-10$ & & $5-8$ & & \\
\hline \multirow[t]{2}{*}{ Lamiaceae } & Ajuga spectabilis Nakai & & & & $6-7$ & & \\
\hline & Salvia chanryoenica Nakai & $6-13$ & & & & & \\
\hline Oleaceae & Fraxinus chiisanensis Nakai & & & & & $10-13$ & $15-16$ \\
\hline \multirow[t]{2}{*}{ Scrophulariaceae } & Melampyrum setaceum var. nakaianum (Tuyama) T. Yamaz. & $4-13$ & & & & & \\
\hline & Scrophularia koraiensis Nakai & $14-17$ & & $14-15$ & $13-14$ & $11-12$ & $10-11$ \\
\hline Campanulaceae & Hanabusaya asiatica (Nakai) Nakai & $16-17$ & & & & & \\
\hline Rubiaceae & Asperula lasiantha Nakai & & & & & & $13-14$ \\
\hline Diervillaceae & Weigela subsessilis (Nakai) L.H. Bailey & & $8-9$ & & $4-9$ & $6-13$ & $5-16$ \\
\hline Caprifoliaceae & Lonicera subsessilis Rehder & $16-17$ & & $8-9$ & & & \\
\hline Valerianaceae & Patrinia saniculifolia Hemsl. & $7-17$ & $15-16$ & & & & \\
\hline \multirow[t]{7}{*}{ Asteraceae } & Aster koraiensis Nakai & & & & $6-7$ & & $4-7$ \\
\hline & Cirsium setidens (Dunn) Nakai & & $8-16$ & $8-15$ & & $12-15$ & $14-17$ \\
\hline & Crepidiastrum koidzumianum (Kitam.) Pak \& Kawano & & & & & $11-15$ & $9-17$ \\
\hline & Parasenecio pseudotamingasa (Nakai) B.U. Oh & & & & & & $11-12$ \\
\hline & Saussurea diamantica Nakai & $10-16$ & & & & & \\
\hline & Saussurea macrolepis (Nakai) Kitam. & & & $13-16$ & & $6-15$ & $13-17$ \\
\hline & Saussurea seoulensis Nakai & $4-17$ & & & $10-13$ & $13-15$ & \\
\hline \multirow[t]{3}{*}{ Cyperaceae } & Carex erythrobasis H. Lév. \& Vaniot & $16-17$ & $8-16$ & $8-16$ & & & \\
\hline & Carex okamotoi Ohwi & & & & $4-13$ & $6-10$ & \\
\hline & Carex subebracteata var. leiosperma (Ohwi) Y.H. Cho \& J. Kim & & & & & & $9-11$ \\
\hline \multirow[t]{5}{*}{ Liliaceae } & Allium thunbergii var. teretifolium H.J. Choi \& B.U. Oh & & & & & $13-15$ & \\
\hline & Heloniopsis koreana S. Fuse, N.S. Lee \& M.N. Tamura & & & $9-11$ & $11-15$ & $14-15$ & \\
\hline & Hemerocallis hakuunensis Nakai & & & & & $13-15$ & \\
\hline & Hosta minor (Baker) Nakai & & & & $9-14$ & $13-15$ & $10-17$ \\
\hline & Lilium amabile Palib. & & & & $10-12$ & & \\
\hline
\end{tabular}


Table 4 Distribution range of the Korean endemic plant species observed in the six national parks of the Baekdudaegan mountain range (Continued)

\begin{tabular}{|c|c|c|c|c|c|c|c|}
\hline \multirow[t]{2}{*}{ Family } & \multirow[t]{2}{*}{ Scientific name } & \multicolumn{6}{|c|}{ Site/elevation $(\times 100 \mathrm{~m})$} \\
\hline & & SR & OD & TB & SB & DG & $\mathrm{JR}$ \\
\hline & Maianthemum bicolor (Nakai) Cubey & $9-17$ & & & & & $15-17$ \\
\hline & Veratrum oxysepalum Turcz. & $9-17$ & $8-16$ & $12-16$ & & & $12-17$ \\
\hline Iridaceae & Iris odaesanensis Y.N. Lee & & & $15-16$ & & & \\
\hline
\end{tabular}

SR Seoraksan National Park, OD Odaesan National Park, TB Taebaeksan National Park, SB Sobaeksan National Park, DG Deogyusan National Park, JR Jirisan National Park

DG), Cimicifuga austrokoreana (1200-1500 $\mathrm{m}$ in JR), and Arabis columnaris (1600-1700 $\mathrm{m}$ in JR) also showed limited distribution in the subalpine zones in some national parks. Future climate change is likely to trigger a crisis for Korean endemic plants in the narrow habitat of the subalpine zone in high mountains, which may already be at the limits of their climatic tolerances.

\section{Conclusions}

This study reveals the elevational distribution ranges of 873 taxa of vascular plants in the six national parks of the Baekdudaegan range through field surveys that apply consistent methods such as survey routes and sections. We focused on conifers, broad-leaved trees, and Korean endemic plants that grow in a cool area over the subalpine zone. Plants that are distributed at high-altitude mountain peak (such as Pinus pumila, Thuja koraiensis, Alnus mandshurica, Rosa koreana, Oplopanax elatus, Hanabusaya asiatica, and Iris odaesanensis) no longer have a niche that can survive through a shift toward the leading edge of cool and cold environments. In order to conserve of the vulnerable plant species to climate change, it is urgently necessary to observe and analyze the patterns of mortality, regeneration, and phenology of the remnant populations at the mountaintops. Our surveys were conducted along one trail (south- or northfacing slope) in national parks. Thus, species distributed under the canopy away from the trail were not included in the list and/or more narrowly determined than their actual distribution ranges. To overcome these limitations, additional investigations should be conducted on other trails based on the consistent survey method in the Baekdudaegan range. In addition, since species' distributions are affected by various environmental factors such as light, moisture, and soil, studies on environmental changes along the elevational gradients will improve the understanding of the vertical distribution of plants in the Baekdudaegan range. Our study provides valuable information on current plant species' elevational distribution ranges in six national parks of the Baekdudaegan range, South Korea, which could serve as a baseline for comparison of the shifts in elevation under future climate change.

\section{Supplementary Information}

The online version contains supplementary material available at https://doi. org/10.1186/s41610-021-00182-1.

Additional file 1: Table S1. Elevational distribution ranges of vascular plant species in the six national parks of the Baekdudaegan mountain range, South Korea. SR Seoraksan National Park, OD Odaesan National Park, TB Taebaeksan National Park, SB Sobaeksan National Park, DG Deogyusan National Park, JR Jirisan National Park.

\section{Abbreviations}

a.s.I.: Above sea level; DG: Deogyusan National Park; JR: Jirisan National Park; OD: Odaesan National Park; RCP: Representative Concentration Pathways; SB: Sobaeksan National Park; SR: Seoraksan National Park; TB: Taebaeksan National Park

\section{Acknowledgements}

We thank anonymous reviewers for helpful comments on the drafts of this article.

Authors' contributions

SS built the database and wrote the manuscript. JHK conducted field study, checked the database, and reviewed the manuscript. JHD built the database and reviewed the manuscript. ISS conceived the study and reviewed the manuscript. BYL designed the study and examined the manuscript. All authors read and approved the final manuscript.

\section{Funding}

This work was supported by a grant from the National Institute of Biological Resources (NIBR), funded by the Ministry of Environment (MOE) of the Republic of Korea (NIBR202027101).

\section{Availability of data and materials}

The datasets generated during and/or analyzed during the current study are available from the corresponding author on reasonable request.

\section{Competing interest}

The authors declare no competing interests.

Ethics approval and consent to participate

Not applicable.

Consent for publication

Not applicable.

\section{Author details}

'Department of Biological Resources Utilization, National Institute of Biological Resources, Incheon 22689, Republic of Korea. ${ }^{2}$ Department of Biological Resources Research, National Institute of Biological Resources, Incheon 22689, Republic of Korea. 
Received: 9 December 2020 Accepted: 8 February 2021

Published online: 02 March 2021

\section{References}

Adhikari P, Shin MS, Jeon JY, Kim HW, Hong S, Seo C. Potential impact of climate change on the species richness of subalpine plant species in the mountain national parks of South Korea. J Ecol Environ. 2018. https://doi.org/10.1186/ s41610-018-0095-y.

An JH, Park HJ, Lee S, Seo IS, Nam GH, Kim JH. Analysis of environmental factors and change of vascular plant species along an elevational gradients in Baekdansa, Mt. Taebaeksan National Park. Korean J Environ Ecol. 2019. https://doi.org/10.13047/KJEE.2019.33.4.378.

An JH, Park HJ, Nam GH, Lee BY, Park CH, Kim JH. Vertical distribution of vascular plant species along an elevational gradients in the Gyebangsan area of Odaesan National Park. Korean J Ecol Environ. 2017. https://doi.org/10.11614/ KSL.2017.50.4.381.

Baekdudaegan National Arboretum. The rare plants of the Baekdudaegan mountains. Daejeon: Korea Forest Service; 2019.

Cahill AE, Aiello-Lammens ME, Fisher-Reid MC, Hua X, Karanewsky CJ, Ryu HY, Sbeglia GC, Spagnolo F, Waldron JB, Warsi O, Wiens JJ. How does climate change cause extinction? Proc R Soc B. 2013. https://doi.org/10.1098/rspb.2 012.1890

Cahill AE, Aiello-Lammens ME, Fisher-Reid MC, Hua X, Karanewsky CJ, Ryu HY, Sbeglia GC, Spagnolo F, Waldron JB, Warsi O, Wiens JJ. Causes of warm-edge range limits: systematic review, proximate factors and implications for climate change. J Biogeogr. 2014. https://doi.org/10.1111/jbi.12231.

Chen IC, Hill JK, Ohlemüller R, Roy DB, Thomas CD. Rapid range shifts of species associated with high levels of climate warming. Science. 2011. https://doi. org/10.1126/science.1206432.

Cho NH, Kim ES, Lee B, Lim JH, Kang S. Predicting the potential distribution of Pinus densiflora and analyzing the relationship with environmental variable using MaxEnt model. Korean J Agric For Meteorol. 2020. https://doi.org/10. 5532/KJAFM.2020.22.2.47.

Chun $\mathrm{JH}$, Lee CB. Assessing the effects of climate change on the geographic distribution of Pinus densiflora in Korea using ecological niche model. Korean J Agric For Meteorol. 2013. https://doi.org/10.5532/KJAFM.2013.15.4.219.

Chung MY, Son S, Suh GU, Herrando-Moraira S, Lee CH, López-Pujol J, Chung MG. The Korean Baekdudaegan Mountains: a glacial refugium and a biodiversity hotspot that needs to be conserved. Front Genet. 2018. https:// doi.org/10.3389/fgene.2018.00489.

Conlisk E, Castanha C, Germino MJ, Veblen TT, Smith JM, Kueppers LM. Declines in low-elevation subalpine tree populations outpace growth in highelevation populations with warming. J Ecol. 2017. https://doi.org/10.1111/13 65-2745.12750.

Damschen El, Harrison S, Grace JB. Climate change effects on an endemic-rich edaphic flora: resurveying Robert H. Whittaker's Siskiyou sites (Oregon, USA). Ecology. 2010. https://doi.org/10.1890/09-1057.1.

Dawson TP, Jackson ST, House JI, Prentice IC, Mace GM. Beyond predictions: biodiversity conservation in a changing climate. Science. 2011. https://doi. org/10.1126/science.1200303.

Fragnière Y, Bétrisey S, Cardinaux L, Stoffel M, Kozlowski G. Fighting their last stand? A global analysis of the distribution and conservation status of gymnosperms. J Biogeogr. 2015. https://doi.org/10.1111/jbi.12480.

Geßler A, Keitel C, Kreuzwieser J, Matyssek R, Seiler W, Rennenberg H. Potential risks for European beech (Fagus sylvatica L.) in a changing climate. Trees. 2007. https://doi.org/10.1007/s00468-006-0107-x.

Hwang SH, Lee JW, La EH, Ahn JK. Flora of the vascular plants of the Baekdudaegan conservation area: Deokchi to Yuksimnyeong. Korean J PI Taxon. 2020. https://doi.org/10.11110/kjpt.2020.50.1.56.

Jump AS, Mátyás C, Peñuelas J. The altitude-for-latitude disparity in the range retractions of woody species. Trends Ecol Evol. 2009. https://doi.org/10.1016/ j.tree.2009.06.007.

Jump AS, Peñuelas J. Running to stand still: adaptation and the response of plants to rapid climate change. Ecol Lett. 2005. https://doi.org/10.1111/j.14610248.2005.00796.x.

Kim BD. Distributional changes of forest vegetation zones and broad-leaved evergreen species of Lauraceae due to climate change in Korea. Ph.D. Dissertation: Yeungnam University, Gyeongsan, Korea; 2016.

Kim ES, Lee JS, Park GE, Lim JH. Change of subalpine coniferous forest area over the last 20 years. J Korean Soc For Sci. 2019. https://doi.org/10.14578/jkfs.201 9.108.1.10.
Kim JH, Kim SY, Park CH, Lee BY, Yun JH. Vertical distribution of vascular plants in Namdeogyusan, Mt. Deogyu National Park by temperature gradient. Korean J. Environ Ecol. 2015a. https://doi.org/10.13047/KJEE.2015.29.5.651.

Kim JS, Kim TY. Woody plants of Korean Peninsula. Paju: Dolbegae; 2011

Kim MS, Cho HJ, Kim JS, Bae KH, Chun JH. The classification of forest vegetation types and species composition in the Sector between Danmoknyeong and Guryongnyeong of Baekdudaegan. Korean J Environ Ecol. 2018. https://doi. org/10.13047/KJEE.2018.32.2.176.

Kim NS, Lee HC. A study on changes and distributions of Korean fir in sub-alpine zone. J Korean Env Res Tech. 2013. https://doi.org/10.13087/kosert.2013.16.5. 049.

Kim TG, Cho Y, Oh JG. Prediction model of pine forests' distribution change according to climate change. Korean J Ecol Environ. 2015b. https://doi.org/1 0.11614/KSL.2015.48.4.229.

Ko SY, Sung JH, Chun JH, Lee YG, Shin MY. Predicting the changes of yearly productive area distribution for Pinus densiflora in Korea based on climate change scenarios. Korean J Agric For Meteorol. 2014. https://doi.org/10.5532/ KJAFM.2014.16.1.72.

Kong WS. Spatio-temporal distributional changes of Bamboo. J Korean Geog Soc. 2001;36:444-57.

Kong WS. Species composition and distribution of native Korean conifers. J Korean Geog Soc. 2004;39:528-43.

Kong WS. Biogeography of native Korean Pinaceae. J Korean Geog Soc. 2006;41: 73-93.

Kong WS. Biogeography of Korean plants. Seoul: GEOBOOK; 2007.

Kong WS, Kim K, Lee SG, Park HN, Cho SH. Distribution of high mountain plants and species vulnerability against climate change. J Environ Impact Assess. 2014. https://doi.org/10.14249/eia.2014.23.2.119.

Koo KA, Kim DB. Review forty-year studies of Korean fir (Abies koreana Wilson). Korean J Environ Ecol. 2020. https://doi.org/10.13047/KJEE.202 0.34.5.358

Korean Fern Society. Ferns and fern allies of Korea. Seoul: GEOBOOK; 2005.

Korea Forest Service. Synthesis report on the second round natural resources change survey and management practice study of the Baekdudaegan Mountains. Daejeon: Korea Forest Service; 2015.

Korea Forest Service. The 6th National forest inventory. Daejeon: Korea Forest Service; 2016.

Körner C. The use of 'altitude' in ecological research. Trends Ecol Evol. 2007. https://doi.org/10.1016/j.tree.2007.09.006.

Lee BC, Shim IS. Environmental and ecological characteristics distribution of natural growth region in Rhododendron Brachycarpum. J Environ Sci. 2011. https://doi.org/10.5322/JES.2011.20.10.1319.

Lee $\mathrm{CB}$, Chun $\mathrm{JH}$. Environmental drivers of patterns of plant diversity along a wide environmental gradient in Korean temperate forests. Forests. 2016. https://doi.org/10.3390/f7010019.

Lee $\mathrm{H}$, Kwon OS. Analyzing the impacts of climate change on forest composition in Korea. Environ Res Econ Rev. 2017. https://doi.org/10.15266/KEREA.2017.2 6.2.229.

Lee HY. The phytosociological characteristics of Abies nephrolepis community and population dynamics as climate condition changes in Mt. Seorak: Korea. Ph. D. Dissertation. Dongguk University, Seoul, Korea; 2013.

Lee S. Analysis of the vulnerability and effects of climate change on plant distribution. MS Thesis: Kyunghee University, Seoul, Korea; 2011.

Lee TB. Coloured flora of Korea. Seoul: Hyangmunsa; 2003.

Lee YN. New flora of Korea. Seoul: Gyohaksa; 2006.

Lenoir JC, Gégout PA, Marquet P, de Ruffray H, Brisse A. A significant upward shift in plant species optimum elevation during the 20th century. Science. 2008. https://doi.org/10.1126/science.1156831.

Loarie SR, Duffy PB, Hamilton H, Asner GP, Field CB, Ackerly DD. The velocity of climate change. Nature. 2009. https://doi.org/10.1038/nature08649.

Mountain Research Initiative EDW Working Group. Elevation-dependent warming in mountain regions of the world. Nat Clim Chang. 2015. https://doi.org/10.1 038/nclimate2563.

Nam GH, Lee BY, Kwak MH, Lim CK, Kim CH, Han KD, Go ES. Inventory and management of endemic species of Korea. Incheon: National Institute of Biological Resources; 2018.

National Institute of Biological Resources. Operation of the Korea biodiversity observation network (K-BON) with civil participation II-2. Incheon: National Institute of Biological Resources; 2018.

National Institute of Biological Resources. National species list of KOREAPlants·Algae.Prokaryotes. Seoul: Designzip; 2019a. 
National Institute of Biological Resources. The Guidebook of Climate Sensitive Biological Indicator Species. Seoul: Goryeo C\&P; 2019b.

National Institute of Meteorological Sciences. Global climate change forecast report. Jeju-do: National Institute of Meteorological Sciences; 2019.

Park HC, Lee HY, Lee NY, Lee H, Song JY. Survey on the distribution of evergreen conifers in the major national park - a case study on Seoraksan, Odaesan, Taebaeksan, Sobaeksan, Deogyusan, Jirisan National Park. J Nat Park Res. 2019;10:224-31.

Park HJ, Ahn JH, Seo I, Lee SR, Lee BY, Kim JH. Distribution pattern of vascular plant species along an elevational gradient in the Samga area of Sobaeksan National Park. J Kor Soc For Sci. 2020. https://doi.org/10.14578/jkfs.2020.1 09.1.1.

Park SU, Koo KA, Kong WS. Potential impact of climate change on distribution of warm temperate evergreen broad-leaved trees in the Korean peninsula. J Korean Geog Soc. 2016:51:201-17.

Parmesan C, Yohe G. A globally coherent fingerprint of climate change impacts across natural systems. Nature. 2003. https://doi.org/10.1038/nature01286.

Trigas P, Panitsa M, Tsiftsis S. Elevational gradient of vascular plant species richness and endemism in Crete - the effect of post-isolation mountain uplift on a continental island system. PLoS ONE. 2013. https://doi.org/10.13 71/journal.pone.0059425.

VanDerWal J, Murphy HT, Kutt AS, Perkins GC, Bateman BL, Perry JJ, Reside AE. Focus on poleward shifts in species' distribution underestimates the fingerprint of climate change. Nat Clim Chang. 2012. https://doi.org/10.1038/ nclimate1688.

Wiens JJ. Climate-related local extinctions are already widespread among plant and animal species. PLoS Biol. 2016. https://doi.org/10.1371/journal.pbio.2 001104.

Worrall JJ, Rehfeldt GE, Hamann A, Hogg EH, Marchetti SB, Michaelian M, Gray LK. Recent declines of Populus tremuloides in North America linked to climate For Ecol Manag. 2013. https://doi.org/10.1016/j.foreco.2012.12.033.

Yi S. Holocene vegetation responses to East Asian monsoonal changes in South Korea. In: Blanco J, Kheradmand H, editors. Climate change - geophysical foundations and ecological effects. London: IntechOpen; 2011.

Yun JH, Kim JH, Oh KH, Lee BY. Vertical distribution of vascular plants in Jungsanri, Mt. Jiri by temperature gradient. Kor Soc Environ Ecol. 2010;24: 680-707.

Yun JH, Kim JH, Oh KH, Lee BY. Distributional change and climate condition of warm-temperate evergreen broad-leaved trees in Korea. Kor J Environ Ecol. 2011;25:47-56

Yun JH, Kim JH, Oh KH, Lee BY. Vertical distribution of vascular plants in Osaek valley, Seoraksan national park by temperature gradient. Kor J Environ Ecol. 2012;26:156-85.

\section{Publisher's Note}

Springer Nature remains neutral with regard to jurisdictional claims in published maps and institutional affiliations.

Ready to submit your research? Choose BMC and benefit from:

- fast, convenient online submission

- thorough peer review by experienced researchers in your field

- rapid publication on acceptance

- support for research data, including large and complex data types

- gold Open Access which fosters wider collaboration and increased citations

- maximum visibility for your research: over $100 \mathrm{M}$ website views per year

At $\mathrm{BMC}$, research is always in progress.

Learn more biomedcentral.com/submissions 